\title{
Impact of physical fitness activities on students' Basic Science achievement in selected Nigerian secondary schools
}

\author{
Bamikole O. Ogunleye ${ }^{1}$, and Oluwasogo Ruth $\mathrm{Ojo}^{2}$
}

\author{
1-Department of Science Education, National Open University of Nigeria, Abuja, Nigeria \\ ORCID ID: 0000-0002-0025-2828 \\ 2-Wesley University, Ondo, Ondo State, Nigeria \\ ORCID ID: 0000-0002-8697-891X
}

Corresponding author contact: bogunleye@noun.edu.ng

\begin{abstract}
Poor student achievement in science is a global challenge. Sustainable Development Goals 3 and 4 targeting people's well-being and quality education as well as the findings of previous studies linking physical exercises to improved student memory and increased concentration become an issue of growing interest and particular relevance. The primary objective of the proposed study, therefore, is to determine the impact of physical fitness activities on students' achievement in Basic Science. The study was a quasi-experiment of a pretest, posttest, control group nature. 125 JS2 students from six schools in Ibadan, Oyo State, Nigeria were covered. Instruments used were stadiometer, gymnasium mats, medicine balls, skipping ropes, cones, stopwatches, weighing scale and Achievement Test in Basic Science $(r=0.84)$. The experimental group was exposed to selected science concepts and physical fitness activities simultaneously, while the instruction in the control group revolved exclusively around concept attainment only. Data analysis employed descriptive statistics and Analysis of Covariance. Physical fitness activities had a significant effect on students' achievement $\left(F_{(1,124)}=347.12 ; P<0.05\right)$. The experimental group got a higher score of 62.58 against the control group $(\bar{x}=53.76)$. Gender, as it happens, had a significant effect on the acquisition of basic science skills $\left(F_{(1,124)}=147.89 ; P<0.05\right)$ with males performing better $(\bar{x}=61.04)$ than females $(\bar{x}=55.29)$. The research yielded no significant effect on the interaction of treatment and gender. Conversely, physical fitness activities were reported to enhance students' capabilities in Basic Science, which is why their subsequent implementation in schools is highly recommended.
\end{abstract}

Keywords: Physical fitness activities, Basic Science, Student achievement, Nigerian schools

\section{Introduction}

The adoption of the Sustainable Development Goals (SDGs), otherwise referred to as the Global Goals by all the United Nations Member States in 2015, is a major action plan towards eradicating extreme poverty, reinforcing our responsibilities in protecting the planet and building peaceful, healthy and prosperous societies by the year 2030 (United Nations, 2016a). The 17 SDGs are closely interrelated as they all recognise that an action in one area will have considerable impact in another. To this end, achieving full gender equality is tightly linked to improving health services and getting every child enrolled in school beyond the primary level and need to be tackled simultaneously. Indeed, SDGs 3, 4 and 5 are specifically designed for ensuring sound health, quality education and a balance in human gender issues respectively (United Nations, 2016b). By and large, knowledge acquisition and skills development hold the keys to unlocking industrial and economic growth, while sustainable development can only be 
assured with education which promotes creativity, research, innovation, poverty eradication and healthy lifestyle (Ogunlela \& Ogunleye, 2014). Science education is a vehicle for moving progressively towards the realization of these goals because it offers both gender group balanced opportunities for knowledge of the universe, life skills for surviving in the universe and correct disposition towards the universe.

Research indicates that the term relevance in science takes various dimensions. Such was the view taken by Stuckey, Sperling, Mamlok-Naaman, Hofstein \& Eilks (2014). In science education, there are three dimensions of relevance (Stuckey, Hofstein, Mamlok-Naaman \& Eilks, 2013) viz: individual, societal and vocational. The three dimensions overlap and contribute to making science relevant to the society. Put together, these three dimensions characterize both the current condition of the individual student as well as their future needs. Science, therefore, explores the intrinsic and extrinsic components equally in favour of the students' environment. Stuckey et al. (2013) and Stuckey et al (2014) analysed the three dimensions as:

Individual: This specifies the type of science education which has the capacity for raising learners' curiosity, attitude, interest and intellectual skills to the extent that the students may go beyond merely passing the course but becoming productive and successful members of the wider society

Societal: This indicates the kind of science education that inculcates into the learners the skills and competencies that could predispose them to become actively involved in the creation of a more sustainable society and contribute actively to its development. The model by Stuckey et al. (2013) and Stuckey et al (2014) for societal-focused science education is designed to develop learners' productive knowledge in a highly systematic way to master the most essential skills and competencies for a more efficient and sustainable society. This will encourage them to contribute significantly to the betterment of the society and make them take more responsibility for the future.

Vocational: This means that tertiary science education curriculum should be designed in ways that develop practical job skills and prepare learners for their successful current and future employability. This kind of science education not only results in higher academic achievement of the learners but also makes them meet the requirements of whatever career they choose to pursue. This implies not merely to secure their students' careers or their high earnings but also guide them on how to become more self-reliant, highly-skilled self-employees or employers of labour who are doing their utmost to contribute effectively to the society's economic growth.

According to Ngema (2016), the model does set good standards of relevance for the science curriculum in schools. It also prepares the ground for the teachers who are active implementers of the curriculum to ensure that all the issues specified in the model are treated in the teaching sessions effectively and direct their efforts to the task of full and efficient development of their learners' capabilities to make economic and social sustainability happen. In Nigeria, although an extremely large number of science teachers are well aware of the problematic science-curriculum implementation, the reverse is the case (Ogunleye, 2007).

Poor performance of students generally is a source of concern. Between 2014 and 2019, the passing percentage to obtain credits in five subjects, including English and Mathematics in the WAECconducted Senior School Certificate Examinations in Nigeria, ranged from 31.28\% in 2014 to $64.18 \%$ in 2019, fluctuating in an unstable rising and falling trend over the years. Of course, these results encapsulated performance in science subjects. Indeed, the current status of science education in Nigeria and other countries around the world present a gloomy picture. In Nigeria, Adaramola (2011) and Bamidele (2014) described this somber tendency very well in their written account of the students' poor performance in secondary school science subjects. But it is Ogunleye (2019a) in particular who raised concerns about the dwindling science education fortunes of students at lower levels of education while Ogunleye (2019b) complained repeatedly about the poor chemistry students' performance at the senior secondary school level. In South Africa, Lemmer and Van Wyk (2010), Muzah (2011), Hlabane (2014) and Ngema (2016) all alluded to the students' under-achievement in science. In Ghana, evidence of poor performance in science education abound (Abreh, Owusu \& Amedahe, 2018; Swars, Daane, \& Giesen, 2006; Swars, Hart, Smith, Smith \& Tolar, 2007; West African Examinations Council [WAEC], 2014, 2015, 2016). The situation in Zambian schools is not different (Mwaba, 2011). In Germany, Stuckey, Sperling, Mamlock-Naaman, Hofstein and Eilks (2014) captured the events of science students' low level of achievement. At the heart of science venture is Basic Science which is taught at the junior school level as a background to further science courses at the senior school level. 
A good performance in science is, therefore, a solid background that would help students' subsequent learning of science at the higher level.

Science education is a disciplined attempt to present students with the concepts, theories and principles in such a way that would help them become literate scientifically and get their verbal (spoken or written) message across clearly and coherently. Science also requires students' ability to collect and analyse data using charts, diagrams and represent the information in words. Students should also be able to appreciate the theories so as to be able to apply them to real life situations (Hlabane, 2014). It is clear that this subject requires from anyone the ability to read, understand and communicate intelligently (Quinn, Lee \& Valdes, 2012). Even at the primary school level, Basic Science practical skills are being emphasized (Famakinwa \& Bello, 2015). These skills, however, could be said to be lacking in students, given their record of dismal performance in science, perhaps due to other extraneous factors beyond effective teaching delivery in the science classroom. As a corollary, students' prerequisite knowledge in science and their attitudes have been found to be at their ebbs, thereby worsening students' capacity for science learning (Ogunleye, 2014).

Several strategies have been advanced for improvement in students' science achievement. These include improved laboratory practical work (Ogunleye, 2010), generative and predict-observe-explain instruction (Babajide (2010) and the inquiry-based approaches (Bamidele, 2014) among others. In addition, one approach to help students stay in the best frame of mind and derive maximum benefits from school activities is physical exercise which has been acclaimed as particularly important for our health status and quality of life. It was postulated to help the brain being and remaining sharp (Tomporowski, 2003). According to Tomporowski, the brain is actually similar in nature to the other muscles in the human body. It is either used for cognitive functions or its capacity is lost. Gym classes are vital for the stimulation of the growth of muscle cells. Physical exercises, most especially aerobic types, are beneficial to the human body and they impact the effective functioning of the brain in several dimensions. These include both the molecular and the behavioural aspects. Godman (2014) stated that there are plenty of benefits that could be gained from peoples' physical activities. Indeed, losing body weight, lowering the blood pressure, a prevention of depression, or just looking better are vital but exercises affect the brain in certain ways that help individuals' memory capacity and improve their critical thinking skills. Godman (2014) also found that regular aerobic exercise not only makes the heart pump well, opens the sweat pores but boosts the size of a person's hippocampus for improved memory in verbal abilities as well as in learning.

According to Tomporowski (2003), exercising for as short as 20 minutes daily facilitates information processing ability and memory as well as the rate of heartbeat. It makes more oxygen available to the brain, stimulating its plasticity and the growth of fresh but additional connections between brain cells. Molteni, heng, Ying, Gómez-Pinilla and Twiss (2004) also made similar discoveries and found that exercises are associated with a drop in stress hormones. For instance, Bjornebekk, Mathe and Brene (2005) reported the antidepressant effect of athletics, like running. In another dimension, BrainHQ (n.d.) reported the alarming rate at which people come down with dementia worldwide. This trend is worrisome but with proper exercises, it could be possibly overcome. Exercise have also been reported as improving individuals' mood and reducing stress and anxiety so you can sleep better at night aiding sleep with a reduction to stress which invariably would reduce the incidence of cognitive malfunction in human beings (Godman, 2014).

Many studies (Scudder, Lambourne, Drollette, Herrmann, Washburn, Dronnelly \& Hillman, 2014; Scudder, Federmeier, Raine, Direito, Boyd, Hillman, 2014; Verburgh, Scherder, van Lange \& Oosterlaan, 2016) have postulated that the pre-frontal cortex and the medial temporal cortex are more voluminous in people who carry out physical exercises as against those who do not. Incidentally, these are brain parts in charge of memory and thinking. It was also found that people who regularly exercise albeit moderately achieved significant improvement in their attention span and could focus more on the learning material (Verburgh, Scherder, van Lange \& Oosterlaan, 2016). A cross-sectional study suggested that regular and intense programme of physical activity in children of 13-14 years in age became more focused on a learning activity beyond the known limits of students' attention capability (Kubesch, Walk, Spitzer, Kammer, Lainburg, Heim \& Hille, 2009).

The gender issue has continued to attract researchers' attention in science education. The field of study has been marked by notable gender disparities in participation, performance and career (Xie \& Shhauman, 2003). These, by all means, have been sources of serious concern. Anderson, Lin, Trea- 
gust, Ross and Yore (2007) noted that males are ahead of females in science learning and achievement. In Iroegbu (1998) and Babajide (2010), the gender question among students' performance in school science was raised. This study conceptualised the critical role which gender still play in science teaching and learning, hence the investigation of gender as a moderator variable in the use of exercises to boost achievement in Basic Science in this study.

With Basic Science as a layer of good background in science and the postulation that physical fitness exercise could foster students' brain development towards good academic performance, the study determined the effect of physical fitness activities, as adjuncts to classroom teaching, on Basic Science achievement of students in selected public secondary schools (junior section) in the Ibadan metropolis in Oyo State of Nigeria. The study also attempts to explore the influence of gender on students' achievement.

\section{Hypotheses}

Three hypotheses were tested.

Hypothesis 1: There is no significantly different measure of achievement in Basic Science between the students in the physical fitness activities group and those in the control one.

Hypothesis 2: Gender has no significant effect on the posttest mean Basic Science achievement scores of the students in the physical fitness activities group and those in the control one.

Hypothesis 3: The interaction effect of treatment and gender on the posttest mean Basic Science achievement scores of students is not significant.

\section{Method}

\subsection{Research Design}

The study was quasi-experimental in approach. It employed the non-randomised design involving pretest and posttest with a control group and within a $2 \times 2$ factorial setting. The treatment of Physical Fitness Exercise as adjuncts to classroom teaching served the experimental dose while the control was offered only classroom teaching without the Fitness Exercise.

\subsection{Selection of Participants}

Six junior secondary schools in Ibadan metropolis of Oyo State, Nigeria were purposively selected for the study based on the set criteria of being:

- Public schools

- Coeducational

- Of a minimum of 10 years of existence

- Willing to allow student participation

From each of the 6 schools, an arm of the JS2 class was randomly selected by balloting. The intact classes got the students who are in such classes purposively included in the study. In all, a total of 125 students (53 males and 72 females) participated in the study. Three schools in each case were randomly assigned to treatment and control groups.

\subsection{Research Instruments}

1. Weighing Scale: Hana portable weight measuring scale (RA 9012), made in England.

2. Stadiometer: SECA 213 portable stadiometer height rod.

3. Medicine balls: $1 \mathrm{~kg}, 2 \mathrm{~kg}$ and $2.5 \mathrm{~kg}$.

4. Gym Mat: Body fit gymnasium mat, made in China.

5. Stop watches

6. Skipping ropes

7. Cones

8. Instructional Guide for Basic Science (IGIST)

9. Basic Science Achievement Test (BSAT)

These instruments were used to collect data germane to the study. All the instruments are standard measuring instruments and physical fitness facilities except the IGIST and BSAT. The IGIST was 
developed to serve as teachers' guide in the teaching of selected Basic Science concepts viz: Living Things, Chemicals, Work, Energy and Power, Types of Energy, Thermal Energy and Crude oil and Petrochemicals. The BSAT is a 25-item multiple-choice objective test on the selected Basic Science Concepts. It was subjected to Kuder-Richardson formula-20 and a reliability of 0.88 with a moderate average item difficulty of 0.47 was obtained.

\subsection{Procedure for the Study}

The schools' permission was obtained for the study to be conducted. Integrated Science and Physical Education teachers were trained in the specific tasks to be carried out. The student-participants and their parents were also made to sign consent forms.

3.4.1 Pretest and Initial Measurements: The following data were collected in the first week:

i. Gender: The sex of the participants was recorded.

ii. Age: The participants' age was recorded in years to the nearest birthday.

iii. Height: Stadiometer was used to measure the participants' height. Each participant was in their sportswear without shoes. The participant stood erect, heels together, knees extended and back against the stand. Measurement was taken in meters to the nearest first decimal place.

iv. Weight: The Hana Portable weighing scale was used to measure the participants' weight. Each participant was in their sportswear without shoes. The weighing scale is calibrated in kilograms from zero to 120 kilogrammes. Weight was recorded to the nearest kilogram.

v. Body Mass Index (BMI): It is a method that estimates body fatness using a mathematical formula i.e. dividing body mass with the square of body height.

Finally, the pretest using the BSAT to measure students' achievement was administered.

3.4.2 Treatment: Based on the experimental procedure adopted by Hajesfandiari, Mehrdad and Karimi (2014), both the experimental and control groups were exposed to classroom teaching of selected Basic Science concepts. While this lasted, only the experimental group had physical fitness activities organised for them. The Physical Training Activities are listed below:

Weeks 1 and 2

Activities: Skipping, dolphin plank, medicine ball back to back pass, squats, seated forward bend, lotus pose and shoulder stand.

Warm-up: The participants had their warm-up for 10 minutes to loosen the muscles and prepare their body for the activities.

Frequency: 3 periods per week.

Intensity: Moderate

Repetition: The participants performed each activity for 30 seconds of a set of exercises repeatedly without interruption.

Rest between activities: 30 seconds.

Cool-down: The participants had a 10-minute cool-down session with light exercises to relax the stressed muscles.

Weeks 3 and 4

Activities: Lunges, zigzag run, sit ups, push-ups, calf raise, mountain pose, bridge pose.

Warm-up: The participants had their warm-up for 10 minutes to loosen the muscles and prepare their body for the activities.

Frequency: 3 periods per week.

Intensity: Moderate.

Repetition: The participants performed each activity for 30 seconds of 3sets repeatedly without interruption within the assigned time.

Rest between activities: 30 seconds.

Rest between sets: Each participant had a 2-minute rest after a set before commencing the second set.

Cool-down: The participants' had a 10-minute cool-down session with light exercises to relax the stressed muscles.

Weeks 5 and 6

Activities: Squats, seated forward bend, lotus pose, shoulder stand, skipping, dolphin plank, Russian twist, standing bicycle crunches. 
Warm-up: The participants had their warm-up for 10 minutes to loosen the muscles and prepare their body for the activities.

Frequency: 3 periods per week.

Intensity: Moderate.

Repetition: The participants performed each activity for 30 seconds of 3 sets repeatedly without interruption within the assigned time.

Rest between activities: 30 seconds.

Rest between sets: Each participant had a 2-minute rest after a set before commencing the second set.

Cool-down: The participants' had a 10-minute cool-down session with light exercises to relax the stressed muscles.

3.4.3 Posttest: The Basic Science Achievement Test (BSAT) was administered in the week succeeding the completion of treatment. This was for both the experimental and control groups.

The study lasted for eight weeks.

\subsection{Method of Data Analysis}

Data were analysed using descriptive and inferential statistics which include frequency count, mean, standard deviation and F-statistic of Analysis of Covariance. Tests were carried out at $\mathrm{p}<0.05$ with inferences based on the guidelines of Akinsola and Ogunleye (2002).

\section{Results}

Hypothesis 1: There is no significantly different measure of achievement in Basic Science between the students in the physical fitness activities group and those in the control one.

Table 1 is on the Summary of ANCOVA.

Table 1: ANCOVA of Treatment and Gender on Achievement in Basic Science

\begin{tabular}{rrrrrrr}
\hline \multicolumn{2}{c}{ Sources of Variance } & $\begin{array}{r}\text { Sums of } \\
\text { Squares }\end{array}$ & df & $\begin{array}{r}\text { Mean } \\
\text { Squares }\end{array}$ & F & P \\
\cline { 2 - 7 } Intercept & Hypothesis & 28418.88 & 1 & 28418.88 & 206.83 & 0.00 \\
& Error & 611.71 & 4.45 & 137.40 & & \\
Pretest & Hypothesis & 33.81 & 1 & 33.81 & 0.43 & 0.51 \\
& Error & 9342.59 & 120 & 77.86 & & \\
Treatment & Hypothesis & 2269.16 & 1 & 2269.16 & 347.12 & $0.03^{*}$ \\
& Error & 7.34 & 1.12 & 6.54 & & \\
Gender & Hypothesis & 963.61 & 1 & 963.61 & 147.89 & $0.04^{*}$ \\
Treatment & Error & 7.26 & 1.11 & 6.52 & & \\
and Gender & Hypothesis & 6.20 & 1 & 6.20 & 0.08 & 0.78 \\
\hline
\end{tabular}

*Significant F-ratio tested at $\mathrm{p}<0.05$

Table 1 shows that the difference in the posttest mean Basic Science achievement of students in the experimental group and that of the control group is significant $\left(\mathrm{F}_{(1,124)}=347.12 ; \mathrm{p}<0.05\right)$. In view of this, the null hypothesis 1 is rejected.

Table 2: Comparison of the Experimental and Control Groups' Basic Science Achievement

\begin{tabular}{lrrrr}
\hline Group & Score & Error & Lowest Score & Highest Score \\
\hline Experimental & 62.58 & 1.07 & 60.46 & 64.69 \\
Control & 53.76 & 1.22 & 51.33 & 56.18 \\
\hline
\end{tabular}

From the results in Table 2 we can conclude that students exposed to the physical fitness activities obtained higher achievement score $(\bar{x}=62.58)$ than their control peers $(\bar{x}=53.78)$. This means that the physical fitness activities have helped to improve students' performance in Basic Science. 
Hypothesis 2: Gender has no significant effect on the posttest mean Basic Science achievement scores of the students in the physical fitness activities group and those in the control one.

From Table 1, the moderating effect of gender on the achievement score of the students on the Basic Science test is significant $\left(\mathrm{F}_{(1,124)}=147.89 ; \mathrm{p}<0.05\right)$. This means that the achievement scores of male and female students are significantly different, hereby hypothesis 2 is rejected.

Table 3: Descriptive Statistics of Male and Female Achievement Scores

\begin{tabular}{lrrrr}
\hline Gender & Score & Error & Lowest Score & Highest Score \\
\hline Male & 61.04 & 1.23 & 58.61 & 63.47 \\
Female & 53.76 & 1.22 & 53.18 & 57.41 \\
\hline
\end{tabular}

Table 3 indicates that male students have higher achievement scores $(\overline{\mathrm{x}}=61.04)$ when compared with the lower score of 53.76 obtained by the female students. This implies that even though both male and female students scored above the 50 percent pass mark, the males did better than the females.

Hypothesis 3: The interaction effect of treatment and gender on the posttest mean Basic Science achievement scores of students is not significant.

Examining the results in Table 1, we can infer that the interaction effect of treatment and gender on students' Basic Science achievement was not significant $\left(\mathrm{F}_{(1,124)}=0.08 ; \mathrm{p}>0.05\right)$. To this effect, the third hypothesis was, therefore, not rejected.

\section{Discussion}

The finding that students who participated in the physical fitness exercise in addition to exposure to the Basic Science concepts performed better than their counterparts who were only taught the Basic Science concepts without such physical fitness exercise benefits has proved the potential of physical exercises at improving students' academic performance. Indeed, the findings lend credence to the assumptions that exercises are associated with faster cell growth in the human hippocampus which is essentially that brain part for learning efficiency and sharp memory (Bjornebekk, Mathé \& Brené, 2005; Godman, 2014). The finding also underscores the necessity for improving science curricula at the implementation stage as canvassed by Akinsola and Ogunleye (2003).

The study proved the complementary relationship between the physical fitness activities and classroom teaching of Integrated Science and argued that it is this effective combination that has resulted in a definite underlying improvement of students' achievement in the subject under discussion. The present study recognizes, still further, the incontrovertible fact that aerobic exercises, like running and swimming, appear to be best for brain health. That is because it increases a person's heart rate to the extent that the body pumps more blood to the brain (Nocturne, 2018). This has not only yielded results in terms of improved concentration, mental alertness and sharp memory but it has translated into high level of mastery of the concepts taught in the period of this investigation. The study has the potentials for reversing the rather gruesome downward trend of students' poor performance towards a more consistent beneficial study of science education for sustainable development.

Another major finding of this study is that gender has a significant effect on students' achievement in Basic Science. Males, inevitably, got the upper hand over their female counterparts. It is, therefore, reasonable to infer that the females, although performed well, need more drive in their learning of science, extra impetus in their Basic Science performance in, as well as perhaps, active participation in sporting activities. It should be pointed out, however, that males benefited more in the combined effect of concept learning in Basic Science and physical fitness activities than the females.

\section{Recommendations}

Based on the foregoing, it is hereby recommended that:

- Teachers of Basic Science and Physical Education should collaborate in instructional delivery and use of fitness exercises to improve students 'achievement in Basic Science. 
- Schools should provide all the required facilities necessary for the successful organization and further integration of physical fitness activities into the students' learning activities.

- Greater efforts need to be made to motivate female students towards regular physical fitness activities to engender improved achievement in Basic Science.

\section{Conclusion}

On the pedestal that exercises impact human brain development, students' memory and learning concentration, it has been established in this study that physical fitness exercise, used as adjuncts to classroom teaching of Basic Science concepts, affected students' achievement in Basic Science to a large extent. In light of this, advanced in the paper is the fair inference that gender is an important factor in the practice of physical fitness activities as well as a relevant consideration towards students' achievement gain in Basic Science within the context of implementation of physical fitness exercises as adjuncts to science learning.

\section{References}

Abreh, M. K., Owusu, K. A. \& Amedahe, F. K. (2018). Trends in Performance of WASSCE Canddates in the Science and Mathematics in Ghana: Perceived Contributing Factors and the Way Forward. https://doi.org/10.1177/0022057418800950

Adaramola, M. O. (2011). Factors related to under-achievement in science, technology and mathematics education (STME) in secondary schools in Rivers State Nigeria. World Journal of Education, 1(1):102-109. https://doi.org/10.5430/wje.v1n1p102

Akinsola, M. K. \& Ogunleye, B. O. (2002). Statistical methods and research design in education. Unpublished mimeograph, Department of Teacher Education, University of Ibadan, Ibadan, Nigeria.

Akinsola, M. K. \& Ogunleye, B. O. (2003). Improving Mathematics curriculum at the implementation stage. O.Ayodele-Bamisaiye, I. A. Nwazuoke \& A. Okediran (Eds.) Education this Millennium: Innovation in Theory and Practice. Ibadan: Macmillan Nigeria Publishers Limited. 211-218. ISBN: 978-018-352-3.

Anderson, J., Lin, H.-S., Treagust, D., Ross, S., \& Yore, L. (2007). Using large-scale assessment datasets for research in science and mathematics education: programme for international student assessment (PISA). International Journal of Science and Mathematics Educa-tion, 5(4), 591614. https://doi.org/10.1007/s10763-007-9090-y

Babajide, V. F. T. (2010). Generative and Predict-Observe-Explain Instructional Strategies as Determinants of Secondary School Students' Achievement and Practical Skills in Physics. Unpublished PhD Thesis, University of Ibadan, Ibadan, Nigeria.

Bamidele, A. D. (2014). Effects of Peer-Led Guided Inquiry and Classwide Peer Tutoring Strategies on the Senior Secondary School Students' Performance and Acquisition of Practi-cal Skills in Chemistry Practical. Unpublished PhD Thesis, University of Ibadan, Ibadan, Nigeria.

BrainHQ (n .d.). Physical Exercise for Brain Health. Retrieved from https://www.brainhq.com/brainresources/everyday-brain-fitness/physical-exercise/

Famakinwa, A. \& Bello, T. O. (2015). Generative and Predict-Observe-Explain Instructional Strategies: Towards Enhancing Basic Science Practical Skills of Lower Primary School Pupils. International Journal of Elementary Education, 4 (4): 86-92. https://doi.org/10.11648/j.ijeedu.20150404.12 
Godman, H. (2014). Regular exercise changes the brain to improve memory, thinking skills. Retrieved from https://www.health.harvard.edu/blog/regular-exercise-changes-brain-improve-memorythinking-skills-201404097110

Hajesfandiari, B., Mehrdad, A. G. \& Karimi, L. (2014). Comparing the effects of convergent and divergent teaching methods on using articles by Iranian EFL learners. International Journal of Educational Investigations, 1 (1): 313-327. Retrieved from http://www.ijeionline.com

Hlabane, A. S. (2014). Exploring effects of incorporating English language in secondary school science education: A case of secondary school Physical Sciences learners in Mpumalanga Province. Unpublished Master of Education dissertation. Pretoria: UNISA.

Iroegbu, T. O. (1998). Problem-based Learning, Numerical Ability and Gender as Determinants of Achievement in Line Graphing Skills in Senior Secondary Physics. An Unpublished Ph.D. Thesis, University of Ibadan, Nigeria.

Jornebekk, A., Mathe, A. A. \& Brene, S. (2004). The antidepressant effect of running is associated with increased hippocampal cell proliferation. International Journal of Neuropsychopharmacology, 8(3):357-68. https://doi.org/10.1017/S1461145705005122

Kubesch, S., Walk, L., Spitzer, M., Kammer, T., Lainburg, A., Heim, R. \& Hille, K. (2009). A 30-min physical education program improves students' executive attention. Mind Brain Education, 3:235-242. https://doi.org/10.1111/j.1751-228X.2009.01076.x

Lemmer, E. \& Van Wyk, N. (2010). Themes in South African Education: For the comparative educationist. Cape Town: Heinemann.

Molteni, R, Zheng J. Q., Ying, Z., Gómez-Pinilla, F. \& Twiss, J. L. (2004). Voluntary exercise increases axonal regeneration from sensory neurons. Proceedings of the National Academy of Science, 101(22):8473-8478. https://doi.org/10.1073/pnas.0401443101

Muzah, P. (2011). An exploration into the school-related factors that cause high matriculation failure rates in Physical science in public high schools of Alexandra Township. Un-published Master of Education Dissertation, University of South Africa.

Mwaba, K. (2011). The performance of female pupils in Physical science at Serenje Technical High School. Academic Production Unit, University of Zambia.

Mwenda, E., Gitaari, E., Nyaga, G., Muthaa, G. \& Reche, G. (2013). Factors contributing to stu-dents' poor performance in mathematics in public secondary schools in Tharaka South district Kenya. Journal of Education and Practice, 4 (7): 93-99.

Ngema, M. H. (2016). Factors that cause poor performance in science subjects at ingwavuma circuit. Unpublished M. Ed. Dissertation, University of South Africa.

Nocturne (2018). 4 things your brain needs daily to thrive. Retrieved 20 September, 2019 from https://nocturne.se/blog/2018/7/3/4-things-your-brain-needs-daily-to-thrive.

Ogunlela, V. B. \& Ogunleye, B. O. (2014). Promoting quality assurance practices for ODL programmes in West Africa higher education institutions: The role of RETRIDAL. International Open and Distance Learning Journal. 4th ACDE 2014 Special Edition, 95-108.

Ogunleye, B. O. (2007). Teachers' perceived barriers to successful implementation of ICT in the teaching and learning of science subjects in Nigerian secondary schools. Nigeria Journal of Computer Literacy, 8(1):1-6. 
Ogunleye, B. O. (2010). Implementation of chemistry practical work in senior secondary schools in Ogun State, Nigeria. African Journal of Educational Management, 13 (2): 227-242.

Ogunleye, B. O. (2014). Prerequisite knowledge and attitudes to Chemistry practical as correlates of students' practical kills and performance in senior school chemistry. Niger-Delta Journal of Education, $6(1 \& 2): 80-88$.

Ogunleye, B. O. (2019a). Strategies for reducing science learning difficulties at lower education-al levels and promoting effective science education in Nigeria. Kampala International University Journal of Education, 14(1):141-154.

Ogunleye, B. O. (2019b). Effects of concrete-representational-abstract instructional strategy on chemistry performance of students with mathematics learning difficulties in Ogun State, Nigeria. Kampala International University Journal of Education,14(2):135-151.

Quinn, H., Lee, O. \& Valdes, G. (2012). Language demands and opportunities in relation to next generation science standards for English language learners: What teachers need to know? Stanford University.

Scudder, M. R., Federmeier, K. D., Raine, L. B., Direito, A., Boyd, J. K., Hillman, C. H. (2014).The association between aerobic fitness and language processing in children: implications for academic achievement. Brain Cognition, 87:140-52. https://doi.org/10.1016/j.bandc.2014.03.016

Scudder, M. R., Lambourne, K., Drollette, E. S., Herrmann, S. D., Washburn, R. A., Donnelly, J. E. \& Hillman, C. H. (2014). Aerobic capacity and cognitive control in elementary schoolage children. Medical Science Sports Exercise, 46(5):1025-35. https://doi.org/10.1249/MSS.0000000000000199

Stuckey, M., Hofstein, A., Mamlok-Naaman, R. \& Eilks, I. (2013). The meaning of 'relevance' in science education and its implications for the science curriculum. Studies in Science Education, 49(1):1-34. https://doi.org/10.1080/03057267.2013.802463

Stuckey, M., Sperling, J., Mamlok-Naaman, R., Hofstein, A. \& Eilks, I. (2014). The societal component in a model of relevance in science education. Department of Biolo-gy/Chemistry, Institute of Science Education, University of Bremen, Germany, Department of science teaching, The Weizmann Institute of Science, Rehovot, Israel.

Swars, S. L., Daane, C. J., Giesen, J. (2006). Mathematics anxiety and mathematics teacher efficacy: What is the relationship in elementary preservice teachers? School Science and Mathematics, 106, 306-315. https://doi.org/10.1111/j.1949-8594.2006.tb17921.x

Swars, S., Hart, L. C., Smith, S. Z., Smith, M. E., Tolar, T. (2007). A longitudinal study of elementary pre-service teachers' mathematics beliefs and content knowledge. School Sci-ence and Mathematics, 107, 325-335. https://doi.org/10.1111/j.1949-8594.2007.tb17797.x

Tomporowski, P. D. (2003). Effects of acute bouts of exercise on cognition. Acta Psychological (Amst). 112(3):297-324. https://doi.org/10.1016/S0001-6918(02)00134-8

United Nations (2016a). Sustainable Develpmet goals. Retrieved from https://www.un.org/sustainabledevelopment/education/

United Nations (2016b). Sustainable Develpmet goals. Retrieved from https://www.un.org/sustainabledevelopment/gender equaliy/ 
Verburgh, L., Scherder, E. J., van Lange, P. A. \& Oosterlaan, J. (2016). The key to success in elite athletes? Explicit and implicit motor learning in youth elite and non-elite soccer players. Journal of Sports Science. 34(18):1782-90.

West African Examinations Council. (2014). Chief examiners report for 2014. Retrieved from https://www.waecgh.org/Portals/0/PDF/General\%20Resume2014.pdf

West African Examinations Council. (2015). Chief examiners report for 2015. Retrieved from https://www.waecgh.org/Portals/0/PDF/General\%20Resume\%20W15.pdf20Resume201 4.pdf

West African Examinations Council. (2016). Chief examiners report for 2016. Retrieved from https://www.waecgh.org/Portals/0/PDF/General\%20Resume\%20W16.pdf

Xie, Y. \& Shauman, K. (2003).Women in Science: CAREER processing and outcomes. Cambridge, Mass: Havard University Press. 